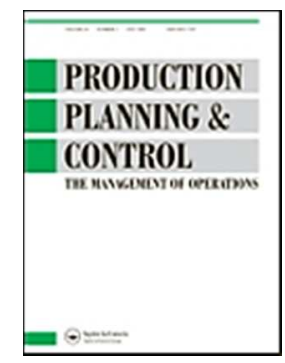

\title{
Inventory Leanness and the Financial Performance of Firms
}

\begin{tabular}{|r|l|}
\hline Journal: & Production Planning \& Control \\
\hline Manuscript ID: & TPPC-2012-0230.R1 \\
\hline Manuscript Type: & Research \\
\hline Date Submitted by the Author: & 15 -Feb-2013 \\
\hline Complete List of Authors: & $\begin{array}{l}\text { Isaksson, Olov; École Polytechnique Fédérale de Lausanne (EPFL), Chair of } \\
\text { Technology and Operations Management } \\
\text { Seifert, Ralf; IMD - International Institute for Management Development, ; } \\
\text { École Polytechnique Fédérale de Lausanne (EPFL), Chair of Technology and } \\
\text { Operations Management }\end{array}$ \\
\hline Keywords: & $\begin{array}{l}\text { empirical operations management, inventory management, inventory } \\
\text { leanness, firm profitability, Compustat data }\end{array}$ \\
\hline
\end{tabular}

SCHOLARONE ${ }^{m}$

Manuscripts 


\title{
Inventory Leanness and the Financial Performance of Firms
}

\author{
Olov H.D. Isaksson ${ }^{\mathrm{a}^{*}}$,Ralf W. Seifert ${ }^{\mathrm{ab}}$ \\ ${ }^{a}$ École Polytechnique Fédérale de Lausanne (EPFL) \\ College of Management of Technology \\ Chair of Technology \& Operations Management \\ Lausanne, Switzerland \\ ${ }^{\mathrm{b}}$ IMD \\ Lausanne, Switzerland \\ * Corresponding author. Email: olov.isaksson@epfl.ch \\ phone: +41 2169324 72, fax: +41216930020
}

URL: http://mc.manuscriptcentral.com/tppc E-mail: ppc@exeter.ac.uk 


\title{
Inventory Leanness and the Financial Performance of Firms
}

\begin{abstract}
This paper examines the financial consequences that inventory leanness has on firm performance. We conduct an econometric analysis using 4,324 publicly traded U.S. manufacturing companies for the period 1980-2008. Using an instrumental variable fixed effects estimator we find a nonlinear relationship between inventory leanness and financial performance. However, we note that the maximum point of this inverted Ushaped relationship often lies at the extreme end of the investigated samplesuggesting a decreasing return from leanness rather than an optimal level. We show that the strength of this relationship is highly dependent on both the industry and inventory component (raw materials, work in process and finished goods) studied. The main novelty and direct implication of our findings is that most firms still have much potential to increase profitability by becoming leaner and they are unlikely to cross a threshold where profitability decreases with increased leanness. We display how much the average firm could gain by becoming leaner and show how this sensitivity changes by inventory component and industry. Finally, we highlight several new econometric aspects that we believe must be addressed when empirically investigating the inventory-performance link.
\end{abstract}

Keywords: empirical operations management, inventory management, inventory leanness, firm profitability, Compustat data

\section{Introduction}

In management literature and the business press, one frequently reads of supply chain success stories such as those of Dell1 ${ }^{1}$ and Zara, ${ }^{2}$ which have reduced inventory to a minimum while retaining quality, service and flexibility. In the last few decades, and especially during the global financial crisis in the late-2000s, inventory reduction has become a widely accepted

\footnotetext{
${ }^{1}$ Through efficient management of inventories and accounts receivable and accounts payable, Dell has achieved a negative cash conversion cycle (Parrino and Kidwell, 2009).

${ }^{2}$ By means of a vertically integrated supply chain, Zara has managed to keep inventories low and profit margins high (Ferdows et al., 2004).
} 
means for firms to reduce costs. Many companies, such as Wal-Mart, ${ }^{3} \mathrm{Chrysler}^{4}$ and GoodYear, ${ }^{5}$ have engaged in inventory reduction programs as a way to improve their cost structure. This behavior mirrors a trade-off that has long played a central role in traditional supply chain research. On the one hand, companies have an incentive to save costs by reducing inventory and hence working capital. On the other hand, firms keep inventory to avoid lost sales and potential operational disruptions. Whereas reduced holding costs can easily be tracked on the balance sheet, shortage costs are much less tangible because lost sales may go unnoticed. As a result, one can easily understand that cutting inventory has become a seemingly attractive way for many firms to reduce costs.

While inventory control models give valuable insights into the sensitivity of the above trade-off, they cannot intrinsically capture the full complexity of a firm. As a consequence, a stream of academic literature has emerged that tries to empirically estimate the relationship between inventory levels and the financial performance of firms. Even though many recent academic studies (Capkun et al., 2009b; Roumiantsev and Netessine, 2007; Chen et al., 2005) support a negative linear association, we remain wary and believe that some inventory management strategies - by underestimating shortage costs - can have a negative overall effect on financial performance. Accounts from practitioners indicate that inventory targets are commonly pushed from the finance department, without a full understanding of the operational and subsequent financial implications. To give an example, it is not uncommon for firms to dramatically push down inventory levels at the end of each financial quarter as a means of "dressing up" the financial report. While this type of practice might boost credit

\footnotetext{
${ }^{3}$ In 2009, Wal-Mart cut its inventory by $8 \%$ in 12 months (Biederman, 2010).

${ }^{4}$ In 2005, due to excessive stock, Chrysler paid dealers to reduce inventory levels (Connelly, 2005).

${ }^{5}$ In 2001, GoodYear made significant production cutbacks due to an inventory reduction pro- gram
}

(Newswire, 2002). 
How do inventory leanness decisions affect the financial performance of firms and what are the factors that govern this relationship?

This research question is central to the field of operations management and of high practical relevance. Yet, empirical evidence of this crucial link remains scarce. Some recent studies (Chen et al., 2005; Roumiantsev and Netessine, 2007; Cannon, 2008; Capkun et al., 2009b; Eroglu and Hofer, 2011b) have recognized this shortcoming and attempted to empirically investigate the link between inventory strategies and the profitability of individual firms. In spite of a common data source (Compustat), their findings to date are not conclusive. While Capkun et al. (2009b) find a positive linear association, Eroglu and Hofer (2011b) find a nonlinear association and Cannon (2008) and Rumyantsev and Netessine (2005) find no significant relationship at all.

Our first contribution is the finding that the maximum point of the inverted U-shaped relationship found by Eroglu and Hofer (2011b) often lies at the extreme end of the 
investigated sample-suggesting a decreasing return from leanness rather than an optimal level. We also find that this effect grows stronger as our analysis becomes more detailed. The direct practical implication is that most firms still have much potential to increase profitability by becoming leaner and they are unlikely to cross a threshold where profitability decreases with increased leanness. To display this point we tabulate our main results and show the percentage of firms below the maximum points. Our second contribution is to analyze the relationship between inventory leanness and financial performance for each subsector and inventory component separately. To our knowledge this is the first study to explicitly demonstrate the large differences in the inventory-performance link and the factors that govern it. Our third contribution lies in performing a more in-depth econometric analysis than previous studies and showing how this statistically significantly changes the results. In particular we correct for endogeneity by using an instrumental variable fixed effects estimator. Also, as opposed to previous research (partial exceptions are Capkun et al. (2009b) and Eroglu and Hofer (2011a)) we break down the analysis both by industry sub-sectors and by the three inventory components of raw materials, work in progress and finished goods. We show that combining these two aspects when exploring how inventory leanness affect financial performance yield additional insights which are necessary to guarantee appropriate recommendations to practicing managers.

The paper is structured as follows. In Section 2 we review the literature from previous. In Section 3 we proceed to discuss our data sample. In Section 4 we present our methodology and key results. In Section 5 we conclude by discussing the limitations of our research as well as its contribution and the implications and potential avenues for further research. 


\section{Literature Review}

Undeniably, inventory efficiency and inventory reduction programs have become widely accepted ways for firms to reduce costs. The first reports of Just in Time (JIT) production in the United States appeared at the beginning of the 1980s (Rajagopalan and Malhotra, 2001). Other inventory efficiency programs such as Vendor Managed Inventory (VMI), Collaborative Planning, Forecasting and Replenishment (CPFR) and Efficient Consumer Response (ECR) quickly followed and gained popularity. Still, in the existing literature there is no strong consensus on how these programs affect the financial performance of firms. Chang and Lee (1995) compare companies that implement JIT with non-implementing firms to find that JIT implementation does not lead to higher operating profit margins. However, they do find that it leads to improved performance in inventory and quality. Huson and Nanda (1995) show that firms adopting JIT increase their inventory turnover and improve earnings. Looking at the Japanese automotive industry, Lieberman and Demeester (1999) establish a negative association between work in progress inventory and manufacturing productivity. Studying a series of continuous reductions over more than six years, they show that, on average, a $10 \%$ reduction in inventory leads to a gain of $1 \%$ in labor productivity. The authors also develop an algorithm that identifies companies that reduced their inventories over a six-year period. Motivated by the wave of inventory management improvement concepts, Rajagopalan and Malhotra (2001) provide evidence, using data from the U.S. Census Bureau, of a decrease in manufacturing inventories between 1961 and 1994. They also show that for half of the 20 manufacturing sectors studied, the decrease was larger in the post-1980 period. These results clearly indicate that over the years companies have changed the way they manage inventories. Olhager (2002) deviates from previous studies by extending the discussion to the link between JIT and the collective efficiency of the supply chain. Similarly, in a case study from the packaging industry, Hofmann and Locker (2009) 


\section{present findings indicating a link between SCM and company value. Additionally, Fullerton}

et al. (2003) survey 253 U.S. manufacturing firms and deduce a positive relationship between different profitability measures and the extent to which JIT has been implemented. Studying
the impact of timely information, Green et al. (2007) show that both JIT-information and
$\underline{\text { logistics performance positively influence organizational performance. Finally, Capkun et al. }}$ (2009a) focus on the value added from inventory reductions and, using annual data, show a strong correlation between the percentage increase in gross margin per employee and the percentage reduction in days of supplies across all manufacturing industries.

In the operations management literature, inventory control models have traditionally been used to gain insights into the trade-offs related to inventory management in various settings. The focus is predominantly on inventory levels rather than working capital. In the finance literature, however, Shin and Soenen (1998) use the net trade cycle as a measurement of working capital and empirically confirm a negative relationship between the length of a firm's net trade cycle and its profitability. Deloof (2003) finds a significant negative relation between gross operating income and the number of days of accounts receivable, inventories and accounts payable for Belgian firms. The negative relation between accounts payable and profitability is explained by the fact that less profitable firms wait longer to pay their bills.

On the empirical side, a recent stream of research has evolved that aims to directly establish a link between inventory management and the financial performance of firms. When examining the spill-over effects of efficient inventory management on other manufacturing practices, Vastag and Whybark (2004) additionally find that inventory turnover is weakly related to overall company performance. Building on the findings of Rajagopalan and Malhotra (2001), Chen et al. (2005) show that American manufacturing companies reduced their inventory holding period by an average of 2\% per year between 1981 and 2000. In addition, by introducing the metric abnormal inventory (Abnormal inventory is the deviation 
in days of inventory from the industry mean normalized by the standard deviation.), defined relative to an industry segment, they further document that firms with slightly less than average inventory have the best long-term stock returns. Similarly, Chen et al. (2007) confirm a downward trend in days of inventory for U.S. retail and wholesale companies and find that firms with abnormally high inventory have abnormally low long-term stock returns. Using Compustat data, Capkun et al. (2009b) study the manufacturing industry and find a positive linear association between inventory performance and financial performance for each of the three inventory components-raw materials, work in progress and finished goods. Looking from an investor's perspective, Kesavan and Mani (2010) show an inverted U-shaped relationship between abnormal inventory growth (as defined by Kesavan et al. (2007).) and one-year ahead of earnings for retailers. Neither Cannon (2008) nor Rumyantsev and Netessine (2005) find a significant relationship between inventory levels and financial performance. Motivated by the mixed evidence with regard to the inventory-performance link, Eroglu and Hofer (2011b) introduce the empirical leanness indicator (ELI) - a measure that takes into account industry-specific inventory characteristics and economies of scale in inventories (it has been shown that if sales increase, in general, inventory levels will increase less than proportionally due to economies of scale (Ballou, 2005).). They find a significant relationship between ELI and firm performance in 36 out of 54 sub-sectors in the manufacturing industry. By assuming a non-linear relationship they also show the existence of an optimal level of inventory in some industries. In a subsequent study, Eroglu and Hofer (2011a) proceed to show that the magnitude of the inventory-performance link differs between raw materials, work in process and finished goods inventories. In addition, they show that the effect of a particular inventory type on performance may, in part, be mediated by another inventory type" (Eroglu and Hofer, 2011a). Finally, another recent study by Kolias et al. (2011) find that inventory turnover is negatively correlated with gross margin 


\begin{abstract}
but positively correlated with capital intensity. In Table 1 we give an overview of the studies
\end{abstract} that are most relevant to our work.

\title{
-- Insert Table 1 around here --
}

As discussed in Section 1, we find a lack of consensus in previous research on the relationship between inventory levels and the financial performance of firms. Capkun et al. (2009b) find a positive linear association, Eroglu and Hofer (2011b) find a non-linear association and Cannon (2008) and Rumyantsev and Netessine (2005) find no significant relationship at all. When a firms make decisions regarding inventory leanness they are faced with the classic trade-off between holding and shortage costs. Keeping this trade-off in mind, one can certainly argue that both too high and too low inventory levels will have a negative effect on the financial performance of the firm. An optimal level of inventory is also in line with classic inventory theory as well as with certain previous empirical results (Chen et al., 2005; Eroglu and Hofer, 2011b). As a point of departure we revisit the non-linearity hypothesis that was tested and partially confirmed by Eroglu and Hofer (2011b). What differs here is our approach: We are particularly interested in how stable these results are to a more exhaustive econometric analysis. In particular we are concerned with: 1) correcting for endogeneity, 2) the heterogeneity across industry segments and inventory components, and 3) investigating different time windows. First, we believe that our model could be subject to endogeneity bias due to both reverse causality (i.e. financial performance also simultaneously affects inventory leanness, not only in the direction we predict in our model) and omitted variables (it is highly unlikely that all relevant controls that correlate with inventory leanness and financial performance can be accounted for using publicly available accounting data). In the presence of endogeneity there is no way of knowing if the estimated 
results even are of the same sign as the true values (Antonakis et al., 2010), even if coefficients are statistically significant. So, without correcting for endogeneity our estimated coefficients cannot be interpreted, even in the correlational sense.

First, we believe that a model testing the above hypothesis will be subject to endogeneity bias due to both reverse causality (i.e. how financial performance simultaneously affects inventory leanness) and omitted variables (it is highly unlikely that all relevant control can be accounted for using publicly available accounting data). In the presence of endogeneity there is no way of knowing if the estimated results even are of the same sign as the true values (Antenakis et al., 2010). For this reason, we view correcting for endogeneity as a necessary step to ensure consistent estimates. If the correction was necessary can later be statistically tested. Second, we believe that the relationship between inventory levels and firm performance is highly dependent on the industry sector and the particular inventory component studied. The sub-sectors within the manufacturing industry differ strongly with regard to factors such as inventory intensity, size, and profitability. Indeed, previous results (Chen et al., 2005; Chen et al., 2007) as well as our preliminary studies show that inventory levels between sub-sectors of the manufacturing industry and between discrete inventory components can differ just as much as between retail and manufacturing. Different focus, too high levels of aggregation and less depth in the analysis could explain why previous studies have found conflicting results. Third, previous studies differ in both the lengths and the periods investigated. Since inventory levels have varied greatly since the 1980s (Chen et al., 2005; Rajagopalan and Malhotra, 2001) we check if our results change over time.

\section{Data}

Like the majority of previous research (see Table 1), our empirical analysis relies on firmlevel data from Standard and Poor's Compustat North America annual database (quarterly 
updates). This database contains information about all companies traded on North American Stock markets and is mainly based on balance sheet data. We are interested in how the inventory-performance link evolves over time, and hence look at a 29-year timeframe, covering the period 1980-2008. Since inventory levels can be expected to be very heterogeneous across different macro sectors, we reduce our focus to manufacturing firms only. A further reason for focusing on the manufacturing sector is that we are interested in the role of the discrete inventory components: raw materials, work in progress and finished goods.

\subsection{Variables}

For measuring financial performance, the EBIT to sales ratio is chosen. This variable has previously been used in studies of the inventory-performance link (Capkun et al., 2009b). EBIT/Sales has the advantages of not being sensitive to firm size as well as representing a good measure of the operational success of a firm. Eroglu and Hofer (2011b) analyze the inventory-performance link using both return on sales (ROS) and return on assets (ROA) as dependent variables. ROS - analogous to EBIT/Sales - is a ratio based on the operating income while ROA is based on net income. Eroglu and Hofer (2011b) find the statistical results to be similar for both measurements but more robust for ROS. This finding also mirrors the results by Kinney and Wempe (2002). Another possibility would have been to use a market valuation metric. It could be argued that such a metric would include the risk perception of the inventory management strategy (as far as this can be observed externally). The stock price might indeed partly reflect such a risk assessment. At the same time, we believe that stock prices also incorporate a wide range of other considerations with no direct bearing on inventory - for example, the outlook on dividend payments, the announcement of corporate share buyback programs or price movements in response to a stock split. In 
addition, stock prices can be highly volatile and speculation-driven depending on the time horizon of investors. Therefore, stock market performance would certainly be a suitable performance measurement for a study aimed at giving advice and insights from an investment perspective. In the context of our research question, however, we consider it more appropriate to follow the approach of Roumiantsev and Netessine (2007); Cannon (2008); Capkun et al. (2009b); Eroglu and Hofer (2011b) and apply an accounting based performance measurement.

The central independent variable concerning inventory levels is computed using the empirical leanness indicator (ELI) and days of inventory. Introduced by Eroglu and Hofer (2011b), the ELI has the advantage of taking into account industry-specific inventory characteristics and economies of scale in inventories. Equation 1 shows the first step in calculating the ELI by regressing the natural logarithm of sales on the natural logarithm of inventory for each of the $i$ industries and $t$ years. In a second step, the ELI for each firm $(f)$ is obtained by studentizing the residuals $(u)$ and multiplying them by -1 so that positive ELI values correspond to lean firms. In the rest of this paper we will refer to the empirical leanness indicator as ELIT (ELI total inventory), ELIRM (ELI raw materials), ELIWIP (ELI work in progress) and ELIFG (ELI finished goods)

$$
\ln \left(\text { inventory }_{i f t}\right)=\alpha_{i t}+\beta_{i t} \ln \left(\text { sales }_{i f t}\right)+u_{i f t}
$$

As a robustness control we also use days of inventory (see equation 2), which represents the number of days of sales that - on average - can be covered with the inventory at hand. For both variables, squared terms are computed in order to trace non-linear relationships between inventory levels and financial performance. 
Days of inventory $=\frac{\text { Inventory }[\$]}{\text { Sales }[\$]} \times 365$

9

Besides the core independent and dependent and variables, several control variables are included. Previous work has shown the importance of controlling for size and sales growth (Chen et al., 2005; Roumiantsev and Netessine, 2007). Therefore sales and the change in sales between years are included in the model. Sales represent the firm size and accounts for the differences between smaller and larger firms. In addition, debt ratio-relating liabilities to total assets -is used as an indicator of the financial situation of a firm. It can be expected that firms with high debt ratios have different financing costs and are, in general, constrained in their operations, leading to a negative influence on the financial performance. As further controls, labor intensity (employees over total assets), capital expenditure intensity (capital expenditures over total assets), selling, general and administrative expense intensity (scaled by assets) and year and firm fixed effects are used. Further controls such as R\&D expenditure were included in a first step but later excluded (with similar results) due to a high level of missing values for these controls. Cost of goods sold should theoretically also be included as a control but due to its high correlation with sales (0.97) we omit it from the model. The effects of this omission should not affect our results when we use instrumental variables in section 4.2 .

\subsection{Data Sampling}

Firms that have gone bankrupt or firms that, for other reasons, are no longer publicly traded will not be present in the subsequent years of our data. To account for this we use an unbalanced panel, whereby all such firms are kept. We cannot give definite answers as to why some firms leave our sample, but our data suggests that financial distress could be a 
reason $^{6}$.-To study potential differences in the inventory-performance link for the different inventory components, we restrict our sample to firm-year observations including values for total, raw materials, work in progress and finished goods inventories. Although this restricts our sample size, an unbiased comparison requires that we keep the same sample when studying each inventory component.

Our preliminary studies indicate that the inventory-performance link of small companies compared with medium to large companies differs significantly. Tables 2 and 3 show the median value of our independent variable (EBIT/Sales) - after cleaning-for different clusters of sales and employees. As can be seen, the smallest firms (in terms of sales and employees) strongly deviate from the rest of our sample. In principle, this would require two separate analyses. However, in this paper we are primarily interested in the effect of inventory efficiency and inventory reduction programs, which are more evident in larger firms. In line with Rumyantsev and Netessine (2005), we therefore limit our study to firms with more than 50 employees and 10 million USD sales (The US Census Bureau classifies small firms either by millions of dollars of sales or by the number of employees. Within the manufacturing industry-depending on the sub-sector-a firm with up to 1.500 employees is classified as small.). In addition, economically insignificant values are removed-i.e. observations with negative inventory or sales levels are excluded since these variables should by definition be positive. We also apply some standard cleaning procedures: Like previous studies (Chen et al., 2005; Cannon, 2008; Capkun et al., 2009b), we proceed to remove outliers from our sample. Looking at the distribution of each variable, one can identify a

${ }^{6}$ Other potential reasons could be delisting, mergers and acquisitions or missing data. Firms that exit our sample prematurely have an average ebit/sales of -0.002 while the average ebit/sales in our 
considerable number of outliers that might induce bias in the analysis. We restrict ourselves to removing only the outlying 1 percent on each side of the distribution.

Insert Table 2 around here

Insert Table 3 around here

Given these basic choices, our sample contains 37,402 firm-year observations on 4,324 firms. Table 4 shows the changes in the sample size as we introduce the control variables mentioned above. Finally, all monetary values are corrected for inflation and adjusted to year 2000 U.S. dollar value.

Within the manufacturing industry we codify each firm to a sub-sector using the Standard Industrial Classification (SIC) code and the classification developed by Fama and French (1997). We have 30 different sub-sectors, of which we exclude 10 because they contain no more than 7 firm-year observations per group. The remaining number of firm-year observation per sub-sector ranges from 35 (Fabricated Products) to 4,097 (Electronic Equipment).

Insert Table 4 around here

\subsection{Descriptive Statistics}

Table 5 provides an overview of the key variables of the analysis over the period from 1980 to 2008. Even though $1 \%$ of outliers are removed, there is still a considerable range in many of the variables. The dependent variable EBIT/Sales has an average value of $5.8 \%$ but a 
standard deviation of $13.2 \%$. However, the EBIT/Sales average is biased by large negative values.

\begin{abstract}
A further control of the interrelation between our variables reveals no high correlations (except between the ELIs but they are analyzed separately). The only relatively high correlation is found between the logarithm of sales and the EBIT/Sales ratio (0.27), indicating a positive relationship between firm size and the operating profit margin.
\end{abstract}

\title{
4 Empirical Results and Discussion
}

In this section we discuss our results and methodological approach for investigating the inventory-performance link. To evaluate the impact of inventory on the financial performance of individual firms, we conduct panel data regression analysis. Firm level data is generally sensitive to omitted variable bias since many unobserved influences and decisions of the firm simultaneously affect the dependent and independent variables. For example, inventory can be expected to be endogenous since it is partly determined by the sales level, which also affects the financial performance. A straightforward solution, in this case, is to include a control variable in all of the models. Still, there are other factors that affect both inventory levels and financial performance that we cannot observe. For example, a drop in raw material prices would likely positively affect the financial performance of the firm (if buying). At the same time, the firm might use the occasion to increase inventory levels. A second potential endogeneity problem arises from reverse causality, which could also affect the results significantly. The need for endogeneity correction has not been addressed in previous studies. What we are interested in here is to investigate how correcting for endogeneity affects our results compared to a standard model. 
Insert Table 5 around here

\subsection{Inventory Leanness and Financial Performance}

In a first step, using fixed effects estimation, we regress ELI on EBIT/Sales for our whole sample of manufacturing firms for the years 1980-2008. We also perform the same analysis using random effects and pooled OLS but standard tests (Wald, Breusch-Pagan and Hausman) show fixed effects to be the only consistent estimator.

EBIT $/$ Sales $=\beta_{0}+\beta_{1}$ ELI It $_{i t}+\beta_{2}$ ELI I $_{i t}^{2}+\beta_{3}$ Log_Sales $_{i t}+\beta_{4}$ Delta_Sales $_{i t}+$ $\beta_{5}$ Debt_ratio $_{i t}+\beta_{6} E_{\text {Emp_at }} a t_{i t}+\beta_{7} C A P X_{-} a t_{i t}+\beta_{8} X S G A_{-} a t_{i t}+\sum \delta_{i} F_{i}+\sum \gamma_{i} Y_{i}+u_{i t}$

Equation 3 shows our generic econometric model where EBIT/Sales ${ }_{i t}$ represents the financial performance for firm $i$ in year $t$; ELI refers to ELIT, ELIRM, ELIWIP or ELIFG (estimated in separate regressions to avoid problems with multicollinearity). Our control

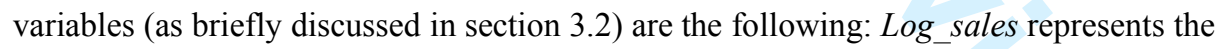
natural logarithm of the dollar value of sales, Delta_sales represents the percentage change in sales between years, Debt_ratio relates liabilities to total assets (both dollar value), Emp_at represents the number of employees scaled by total assets, $C A P X \_a t$ capital expenditure over total assets and finally $X S G A \_a t$ selling, general and administrative expenses scaled by total assets. In addition, year $(Y)$ and industry $(F)$ fixed effects are controlled for.

Estimating equation 3 on our total sample of manufacturing firms (see Table 6) we can confirm our predicted inverted U-shape for total inventory, also shown by Eroglu and Hofer (2011b). We extend their work by showing that this is equally true for each of the three inventory components separately (partly also shown by Eroglu and Hofer (2011a)). Of particular interest here, is that the maximum points lie outside the range (or just at the 
extreme end in the case of ELIRM and ELIWIP) of our sample. So rather than observing a decrease in profitability for the leanest firms, we are observing a decrease in the positive effect of lean inventories. We come back to this here-below and in further depth in Section 4.2. Similar results are obtained when using days of inventory instead of ELI.

\section{Insert Table 6 around here}

In a second step, we perform the same analysis but for each of the 20 sub-sectors separately. Because of limited space we display only the functional form of the relationship between our dependent variable ELI and EBIT/Sales for the Machinery sub-sector, which can be seen in Figure 1 The scale on the y-axis, EBIT/Sales, is common for each sub-sector, over total inventory and the three inventory components. The common y-axis serves as a comparison of the functional form and the sensitivity between ELI and EBIT/Sales . The xaxis shows the empirical leanness indicator, where a high value corresponds to a firm that was leaner (firm size taken into account) than its competitors in a certain year. The graphic is to be interpreted as follows: A non-linear shape is displayed when both the coefficients for ELI and ELI2 were found to be statistically significant on, at least, the ten percent level. A linear relationship corresponds to a statistically significant ELI coefficient but a nonsignificant ELI2. For our 20 sub-sectors the nature of the relationships is summarized in table 7.

Insert Figure 1 around here

Functional form of ELI regressed on EBIT/Sales in the Machinery subsector 1980-2008.

(1)

Formatted: Normal, Left 
Like Eroglu and Hofer (2011b), we find differences between sub-sectors. In addition, we can also show a strong heterogeneity between inventory components within each subsector. The differences can be seen in the functional form, in the strength of the relationship,

\title{
Insert Table 7 around here
}

\begin{abstract}
and in the significance of the relationship. We can, at this point, partly confirm the U-shaped relationship that Eroglu and Hofer (2011b) find in 48\% of their industries. However, when graphing all our regressions similar to figure 1, we do in many cases not observe a clear inverted U-shaped relationship, but rather decreasing effects-i.e. the maximum point lies at the extreme range of our sample. While this has not been shown in previous studies, the practical implication would be that an optimal level of inventory leanness, in these cases, might not actually exist
\end{abstract}

\subsection{Correcting for Endogeneity}

The above results provide new information on the nature of the inventory-performance link and some of the factors that govern it. However, they do not speak to the causality of the relationship. Of particular concern are omitted variable bias and the prevalence of reverse causality-i.e. that financial performance may affect inventory levels (directly or indirectly). We go about correcting for endogeneity in the following way:

We use lagged ELI as instrumental variables. Our argument is that inventory leanness in the previous year should affect inventory leanness in the current year, but not the financial performance of the current year. Indeed, the economics literature has suggested that inventory investments/divestments are phenemenen-phenomena with high cyclical frequency that are often used to reduce working capital on the short-term (Carpenter et al., 1994). Since we use 
annual data, this would support our argument that inventory leanness has little influence on financial performance in the subsequent year's fiscal closing (we discuss our reasons for using annual data in Section 5). We test the strength of our instruments with the KleibergenPaap LM statistic. In all 76 cases we can reject the null hypothesis (the equation is underidentified) at the $1 \%$ level. The Cragg-Donald Wald F-statistic ranges between 4 and 426 with only 2 out of 76 statistics below 10 . These results give us a strong indication that our model is well specified and adequately defined (Baum et al., 2007).

Our estimators do not converge in the case of the Printing and Publishing subsector. This is also the only sub-sector where we observed counterintuitive results in our previous regression (U-shaped for total inventory and negative linear for RM. Not significant for WiP and FG). In Table 8 we summarize our fixed effects instrumental variable regression estimates for all 19 sub-sectors. We base these estimations on equation 3 for every sub-sector and component separately. In all estimations we use cluster and heteroscedasticity robust standard error. We do not report R-square since it has little statistical meaning in the context of $2 \mathrm{SLS} / \mathrm{IV}$. As we have already established the importance of studying each inventory component separately, we do not report the estimates for total inventory. We find that in 42 out of 57 cases our estimates are significantly different compared to when not correcting for endogeneity (significant Davidson-Mackinnon test of exogeneity).

In column 3 in Table 8 we can also better observe the point previously made regarding the functional shape of ELI. In 6 cases (out of 26) at least 95\% of the firms have a lower ELI (i.e. less lean) than the maximum point. In 20 cases, at least $85 \%$ of the firms are below the maximum point. We highlight these cases (including strictly linear relationships) in underlined font. The practical implication of this is that most firms still have much potential to increase profitability by becoming leaner and they are unlikely to cross a threshold where the profitability decreases with increased leanness. We demonstrate this by calculating the 
expected change in EBIT/Sales following a 1 standard deviation increase in ELI from the mean-i.e. becoming leaner (column 4 in Table 8). For the sub-sector Electrical Equipment, a 1 standard deviation increase in ELIRM would (ceteris paribus) on average lead to a 4.7 percentage point increase in EBIT/Sales. However, the same increase in ELIWIP would on average only lead to a 0.1 percentage point increase in EBIT/Sales. This well demonstrates our point regarding the necessity of analyzing the inventory-performance link on disaggregated industry-levels and across inventory components. Our results display strong differences in the inventory-performance link on both these dimensions.

\subsection{Robustness over Time}

Our sample consists of a panel with observations from 1980 to 2008. To control for robustness in our results we divide our sample into three time-clusters (1980-1989, 19901999 and 2000-2008) and make the same panel data IV-regressions as in Section 4.2. For all three time-clusters we find largely the same results as for the whole sample. However, as we go back in time, the number of observations goes down and we find that some non-linear relationships are replaced by linear ones. We have two potential explanations for this. First, it could simply be a case of fewer observations and hence less likelihood of finding two significant coefficients. A second explanation could be that, in the first period (1980-1989), lean practices were new and companies had not yet experienced the negative effects of being too lean-i.e. the thinking was "the leaner the better" and the concept of an optimal level of inventory was less relevant than it is now. We test for the plausibility of these two explanations by running multiple simulations (similar to bootstrapping) for the more recent 


\section{Conclusion}

This research builds on the recent stream of literature (Eroglu and Hofer, 2011b; Capkun et al., 2009b; Cannon, 2008) that investigates the link between inventory levels and financial performance. We base our study on a sample of publicly traded U.S. firms between 1980 and 2008. The empirical leanness indicator (ELI), introduced by Eroglu and Hofer (2011b), is used as a relative measurement of inventory leanness and the analysis is carried out for total inventory as well as the three inventory components (raw materials, work in process, finished goods) for 20 sub-sectors in the manufacturing industry. Our results not only confirm the necessity of breaking down the analysis into sub-sectors within the manufacturing industry, but also show strong heterogeneity between the different inventory components. By using lagged levels of ELI as instrumental variables we attempt to correct for endogeneity. When doing this, our results are significantly different to the plain fixed-effects regressions in 42 out of 57 cases. Another interesting finding is that, in many cases, we do not observe an inverted U-shaped relationship with an optimal level of inventories, but rather decreasing positive effects on financial performance-i.e. the maximum point lies at the extreme end of our sample. We tabulate our results and-amongst others-display the strong differences in 
the inventory-performance link within each sub-sector.

Further, by dividing our sample into three time periods (1980-1989, 1990-1999, 2000-2008), we test the robustness of our results and investigate how the inventory performance-link has evolved over time. We find a tendency toward more linear relationships for the earliest time period. Simulations, in which we randomly select firms, show that this effect could be due to a lower number of observations during this time period, rather than a significant difference in the inventory-performance link. A strength and weakness of this research is the large sample of firms, providing a representative analysis for medium to large firms in the U.S. manufacturing industry. At the same time, because of our selection, we cannot make any certain statements about whether our results can be generalized to other industries or not. Also, the use of firm-level accounting data brings several concerns. The first, and major, concern is the presence of endogeneity. We attempt to correct for this by using lagged inventory leanness as instrumental variables. A second concern is the reliability of our data. Not only could our data contain unidentifiable human errors, but balance sheet data can also be subject to manipulations, as studied in the field of earnings management. Finally, we use annual data instead of quarterly. This restricting is purely related to data availability and the fact that the collection of quarterly data on inventory components in Compustat started in 2005.

\footnotetext{
Our findings have direct and important implications for managers. First, using a slightly different setting, our study confirms previous foundational results on the link between inventory and financial performance. The results show that well managed inventories can give companies a competitive advantage, and result in superior financial performance. Second, we show that most firms still have much potential to increase profitability by becoming leaner and they are unlikely to cross a threshold where profitability decreases with increased leanness. To display this point we tabulate the percentage of firms below the maximum points in each industry. Third, by calculating the expected change in EBIT/Sales caused by a standard deviation increase in ELI from the mean, we show how inventory leanness influences profitability differently across industries and inventory
} 


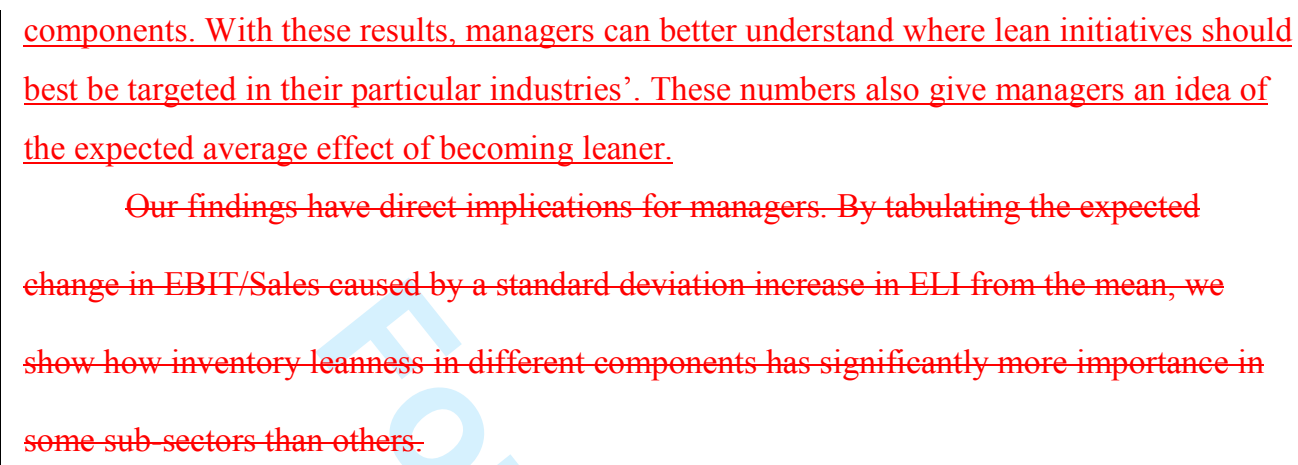

There are a number of areas where future research could be of importance. First, it would be interesting to match balance sheet data with survey data covering firm strategy, competitive environment, product life cycles, product mix, inventory initiatives and the like. We believe this could give a more detailed view and lead to a better understanding of how firms are affected by inventory decisions. One could easily imagine that the inventory reduction programs that are common practice in many firms during recessions could have negative side effects in the long term. A survey approach could be used to study the influence of such inventory changes and give insights into why lean inventory strategies work better for some firms than other. Second, as we find strong heterogeneity between inventory components, it would be worth pursuing the study of these differences and also to explore the existence of an optimal inventory component ratio. Finally, we demonstrate a strong difference between small and medium to large firms. We feel that more work is needed in order to better understand the causes of these differences. 


\section{References}

Antonakis, J., Bendahan, S., Jacquart, P., Lalive, R. (2010), "On making causal claims: A review and recommendations", The Leadership Quarterly, Vol. 21, pp. 1086-1120.

Ballou, R. (2005), "Expressing inventory control policy in the turnover curve", Journal of Business Logistics, Vol. 26, pp. 143-164.

Baum, C. F., Schaffer, M. E., Stillman, S. (2007), "Enhanced routines for instrumental variables/GMM estimation and testing", Working Paper No. 667, Boston College Economics, Boston, Available at: $\mathrm{ftp}: / / \mathrm{ftp}$. iwhhalle.de/pub/vwgr/zipp_lit/econometrics/Weak\%20instruments/stata weakinstruments.pdf.

Biederman, D. (2010). "Home Improvement on the Supply Chain", The Journal of Commerce, 31 May.

Cannon, A. R. (2008), "Inventory improvement and financial performance", International Journal of Production Economics, Vol. 115, pp. 581-593.

Capkun, V., Hameri, A., Weiss, L. A. (2009a), "Measuring the Effects of Improvements in Operations Management", Reiner, Rapid Modelling for Increasing Competitiveness, Springer London, pp. 249-264.

Capkun, V., Hameri, A., Weiss, L. A. (2009b), "On the relationship between inventory and financial performance in manufacturing companies", International Journal of Operations \& Production Management, Vol. 29, pp. 789-806.

Carpenter, R. E., Fazzari, S. M., Petersen, B. C., Kashyap, A. K., Friedman, B. M. (1994), "Inventory investment, internal finance fluctuations, and the business cycle", Brookings Papers on Economic Activity, Vol. 1994, No. 2, pp. 75-138. 
Chang, D., Lee, S. M. (1995), "Impact of JIT on organizational performance of U.S. firms", International Journal of Production Research, Vol. 33, pp. 3053-3068.

Chen, H., Frank, M. Z., Wu, O. Q. (2005), "What Actually Happened to the Inventories of American Companies Between 1981 and 2001? ", Management Science, Vol. 51, pp. 1015-1031.

Chen, H., Frank, M. Z., Wu, O. Q. (2007), "U.S. Retail and Wholesale Inventory Performance from 1981 to 2004", Manufacturing \& Service Operations Management, Vol. 9, pp. 430-456.

Connelly, M. (2005), "Chrysler pays dealers to reduce stock; Company fills parking lots with overproduction", Automotive News, 12 December.

Deloof, M. (2003), "Does Working Capital Management Affect Profitability of Belgian Firms?", Journal of Business Finance \& Accounting, Vol. 30, pp. 573-587.

Eroglu, C., Hofer, C. (2011a), "Inventory Types and Firm Performance: Vector Autoregressive and Vector Error Correction Models", Journal of Business Logistics, Vol. 32, pp.227-239.

Eroglu, C., Hofer, C. (2011b), "Lean, leaner, too lean? The inventory-performance link revisited", Journal of Operations Management, Vol. 29, No. 4, pp. 356-369.

Fama, E. F., French, K. R., (1997), "Industry costs of equity", Journal of Financial Economics, Vol. 43, pp.153-193.

Ferdows, K., Lewis, M. A., MacHuca, J. A. (2004), "Rapid-Fire Fulfillment", Harvard Business Review, Vol. 82, November.

Fullerton, R. R., McWatters, C. S., Fawson, C. (2003), "An examination of the relationships between JIT and financial performance", Journal of Operations Management, Vol. 21, pp. 383-404. 


\section{Green Jr, K. W., Whitten, D., Inman, R. A. (2007). "The impact of timely information on} organisational performance in a supply chain", Production Planning and Control, Vol. 18, pp. 274-82.

Hendricks, K. B., Singhal, V. R. (2003), "The effect of supply chain glitches on shareholder wealth", Journal of Operations Management, Vol. 21, pp. 501-522.

\section{Hofmann, E., Locker, A. (2009). "Value-based performance measurement in supply chains: a} case study from the packaging industry", Production Planning and Control, Vol. 20, pp. $68-81$.

Huson, M., Nanda, D. (1995), " The impact of just-in-time manufacturing on firm performance in the U.S. " Journal of Operations Management, Vol. 12, pp. 297-310.

Kesavan, S., Gauer, V., Raman, A. (2007), "Incorporating Price and Inventory Endogeneity in Firm-Level Sales Forecasting", working paper. Available at: http://server1.tepper.cmu.edu/Seminars/docs/Gaur kgr.pdf.

Kesavan, S., Mani, V. (2010), "The predictive power of abnormal inventory growth: Application to earnings forecasting for retailers", working paper. Available at SSRN: http://ssrn.com/abstract=1541141.

Kinney, M. R., Wempe, W. F. (2002). "Further Evidence on the Extent and Origins of JIT's Profitability Effects", The Accounting Review, Vol. 77, pp. 203-225.

Kolias, G. D., Dimelis, S. P., Filios, V. P. (2011), "An empirical analysis of inventory turnover behaviour in Greek retail sector: 2000-2005", International Journal of Production Economics, Vol. 133, pp.143-153.

Lieberman, M. B., Demeester, L. (1999), "Inventory Reduction and Productivity Growth: Linkages in the Japanese Automotive Industry", Management Science, Vol. 45, pp. 466-485.

Newswire (2002). "Goodyear Reports Results for 2002's First Quarter", 24 April. 


\section{Olhager, J. (2002), "Supply chain management: A just-in-time perspective", Production} Planning and Control, Vol. 13, pp. 681-687.

Parrino, R., Kidwell, D. (2009), Fundamentals of Corporate Finance, Wiley.

Rajagopalan, S., Malhotra, A. (2001). "Have U.S. Manufacturing Inventories Really Decreased? An Empirical Study", Manufacturing \& Service Operations Management, Vol. 3, pp.14-24.

Roumiantsev, S., Netessine, S. (2007), "Inventory and its relationship with profitability: Evidence for an international sample of countries", working paper, University of Pennsylvania, Philadelphia, PA, Availabe at:

http://www.d1128066.domain.com/RoumiantsevNetessine.pdf.

Rumyantsev, S., Netessine, S. (2005), "Should inventory policy be lean or responsive? Evidence for U.S. public companies", working paper, University of Pennsylvania, , Philadelphia, PA, Available at: http://opim.wharton.upenn.edu/ netessin/ROA.pdf.

Shin, H. H., Soenen, L. (1998), "Efficiency of Working Capital Management and Corporate Profitability", Financial Practice and Education, Vol. 8, No. 2, pp. 37-45.

Vastag, G., Whybark, D. C. (2004). "Inventory management: Is there a knock-on effect? ", International Journal of Production Economics, Vol. 93-94, pp. 129-138. 
Machinery 3116 observations on 353 firms.

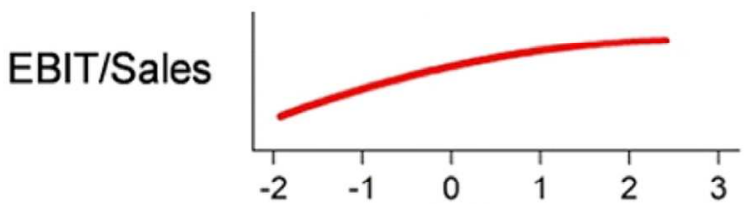

ELI total inventory

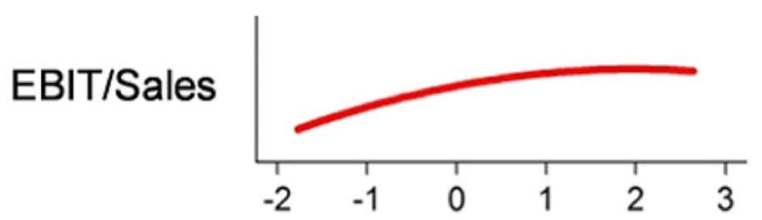

ELI WiP inventory

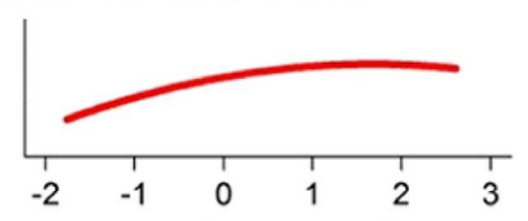

ELI RM inventory

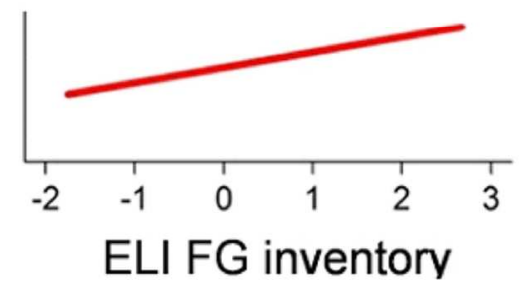

$103 \times 54 \mathrm{~mm}(300 \times 300$ DPI $)$ 


\begin{tabular}{|c|c|c|c|c|c|c|}
\hline Study & Sample & Inventory measurement & $\begin{array}{l}\text { Performance } \\
\text { measurement }\end{array}$ & Methodology & Aspect studied & Results \\
\hline Chen et al. (2005) & $\begin{array}{l}\text { Compustat Manufacturing industry } \\
\text { 1981-200. 61,000 firm-years. Yearly } \\
\text { data on total inventory. }\end{array}$ & $\begin{array}{l}\text { Abnormal inventory } \\
\text { (unit free measurement relative } \\
\text { to industry sub-sector). }\end{array}$ & $\begin{array}{l}\text { Stock market } \\
\text { return. }\end{array}$ & $\begin{array}{l}\text { Returns of } \\
\text { portfolios sorted } \\
\text { by abnormal } \\
\text { inventory. }\end{array}$ & $\begin{array}{l}\text { 1) Inventory trend between } \\
1981 \text { and 2000. 2) Link } \\
\text { between inventory levels and } \\
\text { firm value. }\end{array}$ & $\begin{array}{l}\text { Firms with abnormally high inventories have } \\
\text { abnormally poor long-term stock returns. Firms } \\
\text { with slightly lower than average inventories } \\
\text { have good stock returns, but firms with the } \\
\text { lowest inventories have only ordinary returns. }\end{array}$ \\
\hline $\begin{array}{l}\text { Rumyantsev and } \\
\text { Netessine (2005) }\end{array}$ & $\begin{array}{l}\text { Compustat Retail, Wholesale and } \\
\text { Manufacturing industry } 1992-2002.722 \\
\text { firms. Quarterly data on total inventory. }\end{array}$ & $\begin{array}{l}\text { Days of inventory } \\
\text { (average days of sales that can be } \\
\text { covered with inventory). }\end{array}$ & $\begin{array}{l}\text { Return on assets } \\
\text { (ROA). }\end{array}$ & $\begin{array}{l}\text { Two-step } \\
\text { econometric } \\
\text { model. }\end{array}$ & $\begin{array}{l}\text { 1) Association between } \\
\text { earnings and responsiveness in } \\
\text { inventory management. 2) } \\
\text { Association between inventory } \\
\text { levels and financial } \\
\text { performance. }\end{array}$ & $\begin{array}{l}\text { No significant relationship between inventory } \\
\text { levels and future profitability. Responsiveness } \\
\text { in inventory management matters more to } \\
\text { profitability than absolute inventory levels. }\end{array}$ \\
\hline Chen et al. (2007) & $\begin{array}{l}\text { Compustat Retail and Wholesale } \\
\text { industry from } 1981 \text { to } 2004.10,000 \text { firm- } \\
\text { years. Yearly data on total inventory is } \\
\text { used to analyze the inventory- } \\
\text { performance link. }\end{array}$ & $\begin{array}{l}\text { Abnormal inventory } \\
\text { (unit free measurement relative } \\
\text { to industry sub-sector). }\end{array}$ & $\begin{array}{l}\text { Stock market } \\
\text { return. }\end{array}$ & $\begin{array}{l}\text { Returns of } \\
\text { portfolios sorted } \\
\text { by abnormal } \\
\text { inventory. }\end{array}$ & $\begin{array}{l}\text { 1) Inventory trend between } \\
1981 \text { and 2004. 2) Link } \\
\text { between inventory levels and } \\
\text { firm value. }\end{array}$ & $\begin{array}{l}\text { Firms with abnormally high inventories have } \\
\text { abnormally poor long-term stock returns. }\end{array}$ \\
\hline Cannon (2008) & \begin{tabular}{|l|} 
Stern Stewart Performance $1000^{\oplus}$. \\
Manufacturing industry $1991-2000.244$ \\
firms and 2440 firm-year observations. \\
Yearly data on total inventory.
\end{tabular} & $\begin{array}{l}\text { The percentage change in } \\
\text { inventory turnover from the } \\
\text { previous year. }\end{array}$ & $\begin{array}{l}\text { Return on Assets } \\
\text { (ROA) \& } \\
\text { Return on } \\
\text { Investment (ROI). }\end{array}$ & $\begin{array}{l}\text { Hierarchical linear } \\
\text { modeling (HLM). }\end{array}$ & $\begin{array}{l}\text { Review the two contrasting } \\
\text { views of inventory as an } \\
\text { indicator of financial } \\
\text { performance. }\end{array}$ & $\begin{array}{l}\text { Little or no relationship between inventory and } \\
\text { financial performance. }\end{array}$ \\
\hline Capkun et al. (2009b) & \begin{tabular}{|l|} 
Compustat Manufacturing industry \\
1980-2005. 52,254 firm-year \\
observations. Yearly data on component \\
level (RM, WiP, FG).
\end{tabular} & \begin{tabular}{|l|} 
Days of inventory \\
(average days of sales that can be \\
covered with inventory).
\end{tabular} & $\begin{array}{l}\text { EBIT/Sales \& } \\
\text { Gross profit/Sales }\end{array}$ & OLS regression & $\begin{array}{l}\text { Relationship between inventory } \\
\text { levels and financial } \\
\text { performance. }\end{array}$ & $\begin{array}{l}\text { A significant positive correlation between } \\
\text { inventory performance and financial } \\
\text { performance. For total inventory as well as for } \\
\text { all inventory components (RM, WiP, FG). }\end{array}$ \\
\hline $\begin{array}{l}\text { Eroglu and Hofer } \\
\text { (2011b) }\end{array}$ & $\begin{array}{l}\text { Compustat Manufacturing Industry } \\
2003-2008.1600 \text { firms and } 7804 \text { firm- } \\
\text { year observations. Yearly data on total } \\
\text { inventory. }\end{array}$ & \begin{tabular}{|l|} 
Empirical leanness indicator \\
(ELI)-a theory based measure of \\
inventory leanness taking into \\
account industry and economies \\
of scale in inventories.
\end{tabular} & \begin{tabular}{|l|} 
Return on assets \\
(ROA) \& Return on \\
sales (ROS)
\end{tabular} & $\begin{array}{l}\text { Fixed effects } \\
\text { regression. }\end{array}$ & $\begin{array}{l}\text { 1) A new, theory-based, } \\
\text { measurement of inventory } \\
\text { leanness. 2) Inventory- } \\
\text { performance link. }\end{array}$ & $\begin{array}{l}\text { The significance and shape of the inventory- } \\
\text { performance link varies across industries. The } \\
\text { relationship is significant in } 2 / 3 \text { of industries } \\
\text { and predominantly concave, suggesting an } \\
\text { optimal level of inventory leanness. }\end{array}$ \\
\hline
\end{tabular}

Table 1: Overview of the most related empirical studies on the inventory-performance link 


\begin{tabular}{ll}
\hline Number of employees & Median EBIT/Sales \\
\hline $0-50$ & -0.404 \\
$51-100$ & -0.072 \\
$101-500$ & 0.035 \\
$501-1000$ & 0.065 \\
$1001-$ & 0.077 \\
\hline
\end{tabular}

Table 2: Median EBIT/Sales categorized by number of employees

\begin{tabular}{ll}
\hline Sales in million USD & Median EBIT/Sales \\
\hline $0-10$ & -0.258 \\
$11-25$ & 0.03 \\
$26-50$ & 0.049 \\
$51-100$ & 0.062 \\
$101-$ & 0.082 \\
\hline
\end{tabular}

Table 3: Median EBIT/Sales by sales category

\begin{tabular}{lll}
\hline Sample & Observations & Firms \\
\hline Original sample of manufacturing firms between 1980 and 2008 & 37402 & 4324 \\
Including percentage change in sales between Yt \& Yt-1 & 34563 & 4134 \\
Including labor intensity (employees/total assets) & 32745 & 3982 \\
Including debt ratio & 32285 & 3957 \\
Including capital expenditure intensity (capital exp./total assets) & 31727 & 3930 \\
Including selling, general and admin. expense intensity & 31006 & 3859 \\
\hline
\end{tabular}

Table 4: Number of observations and firms in sample after adding control variables 


\begin{tabular}{|c|c|c|c|c|c|c|c|c|c|c|c|c|c|c|}
\hline & mean & sd (1) & 12 & 2) & $(3)$ & $(4)$ & $(5)$ & $(6)$ & 7) & & 9) & $(10)$ & (11) & \\
\hline (1) Operating profit margin (EBIT/Sales) & 0.058 & 0.132 & 1 & & & & & & & & & & & \\
\hline (2) ELI total inventory & -0.075 & 0.776 & 0.0781 & 1 & & & & & & & & & & \\
\hline (3) ELI raw material inventory & -0.063 & 0.794 & 0.0557 & 0.4958 & 1 & & & & & & & & & \\
\hline (4) ELI work in process inventory & -0.018 & 0.831 & 0.0217 & 0.4728 & 0.1426 & 1 & & & & & & & & \\
\hline (5) ELI finished goods inventory & -0.031 & 0.821 & 0.0449 & 0.5996 & 0.0308 & 0.0048 & 1 & & & & & & & \\
\hline (6) Logged sales (year 2000 USD million) & 5.353 & 1.741 & 0.2663 & -0.0004 & 0.0285 & -0.0027 & -0.0162 & 1 & & & & & & \\
\hline (7) Change in sales (percentage between Yt and Yt-1) & 0.178 & 0.315 & 0.136 & 0.0288 & -0.0134 & 0.0205 & 0.0564 & -0.0778 & 1 & & & & & \\
\hline (8) Employees/total assets & 0.014 & 0.013 & 0.0142 & 0.0538 & -0.0079 & -0.0026 & 0.0543 & -0.3039 & -0.0364 & 1 & & & & \\
\hline (9) Debtratio (total liabilities/total assets' & 0.5 & 0.25 & -0.0982 & -0.0037 & 0.0178 & 0.0137 & -0.0104 & 0.2312 & -0.1186 & 0.0375 & 1 & & & \\
\hline (10) Capital expenditure/total assets & 0.054 & 0.041 & 0.1158 & 0.1239 & 0.0645 & 0.0258 & 0.112 & 0.019 & 0.1227 & 0.1419 & -0.0841 & 1 & & \\
\hline (11) Selling, general and admin. expense /total assets & 0.313 & 0.206 & -0.2827 & 0.1079 & 0.1026 & 0.1606 & -0.022 & -0.3107 & -0.0198 & 0.1074 & -0.0813 & -0.0357 & & 1 \\
\hline Observations & 31006 & & & & & & & & & & & & & \\
\hline
\end{tabular}

Table 5: Descriptive statistics and correlation table 


\begin{tabular}{lcccc}
\hline & $(1)$ & $(2)$ & $(3)$ & $(4)$ \\
Ebit/Sales & & & & \\
\hline ELIT & $0.0321^{* * *}$ & & & \\
ELIT $^{2}$ & $-0.00380^{* * *}$ & & & \\
ELIRM & & $0.0206^{* * *}$ & & \\
ELIRM & & & \\
ELIWIP & & $-0.00600^{* * *}$ & & \\
ELIWIP & & & $0.0186^{* * *}$ & \\
ELIFG & & $-0.00531^{* * *}$ & \\
ELIFG & & & $0.0261^{2 * *}$ \\
Delta_sales & & & & $-0.00334^{* * *}$ \\
Log_sales & & & & \\
Emp_at & $0.0746^{* * *}$ & $0.0763^{* * *}$ & $0.0766^{* * *}$ & $0.0738^{* * *}$ \\
Debt_ratio & $0.0435^{* * *}$ & $0.0440^{* * *}$ & $0.0422^{* * *}$ & $0.0432^{* * *}$ \\
CAPX_at & $-0.599^{* * *}$ & $-0.427^{* * *}$ & $-0.414^{* * *}$ & $-0.511^{* * *}$ \\
XSGA_at & $-0.103^{* * *}$ & $-0.105^{* * *}$ & $-0.106^{* * *}$ & $-0.103^{* * *}$ \\
Constant & $0.119^{* * *}$ & $0.138^{* * *}$ & $0.132^{* * *}$ & $0.118^{* * *}$ \\
Year effects included & $-0.273^{* * *}$ & $-0.261^{* * *}$ & $-0.252^{* * *}$ & $-0.246^{* * *}$ \\
\hline Observations & $-0.182^{* * *}$ & $-0.189^{* * *}$ & $-0.177^{* * *}$ & $-0.184^{* * *}$ \\
Number of Firms & Yes & Yes & Yes & Yes \\
Adj. R-Square & 31006 & 31006 & 31006 & 31006 \\
Within R-Square & 3859 & 3859 & 3859 & 3859 \\
F statistic & 0.0625 & 0.0453 & 0.0415 & 0.05 \\
\hline & 0.184 & 0.169 & 0.165 & 0.173 \\
\hline & 167.7 & 151.3 & 147.7 & 155.8 \\
\hline ( & & & \\
\hline
\end{tabular}

${ }^{*}(p<0.05),{ }^{* *}(p<0.01), * * *(p<0.001)$

Table 6: Regression of ELI on EBIT/Sales for all manufacturing firms 1980-2008

\begin{tabular}{lccc}
\hline Type \Relationship & Quadratic & Linear & Not significant \\
\hline Total inventory & 8 & 9 & 3 \\
Raw material inventory & 10 & 4 & 6 \\
Work in progress invento & 10 & 3 & 7 \\
Finished goods inventory & 7 & 8 & 5 \\
\hline
\end{tabular}

Table 7: Summary of functional relationship between ELI and EBIT/Sales for the 20 sub-sectors 


\begin{tabular}{|c|c|c|c|c|c|c|c|c|c|c|c|c|c|c|c|}
\hline Industry & $\begin{array}{l}\text { Inventory } \\
\text { Componen } \\
\text { t }\end{array}$ & $\begin{array}{l}\text { Percentile } \\
\text { before } \\
\text { maximum } \\
\text { point }\end{array}$ & $\begin{array}{l}\text { Change in } \\
\text { ebit/sales by } \\
\text { one s.d. } \\
\text { increase in ELI }\end{array}$ & ELI & $\mathrm{ELI}^{2}$ & Delta_sales & Log_sales & Emp_at & Debt_ratio & CAPX_at & XSGA_at & $\mathrm{N}$ & Firms & $\begin{array}{l}\text { Kleiberge } \\
\text { n-Paap } \\
\text { statistic }\end{array}$ & $\begin{array}{l}\text { Davidson- } \\
\text { MacKinnon } \\
\text { test of } \\
\text { exogeneity }\end{array}$ \\
\hline Electronic Equipment & RM & $91.6 \%$ & $5.94 \%$ & $0.101^{* * *}$ & $-0.042 * * *$ & $0.106^{* * *}$ & $0.030^{* * *}$ & $0.718^{* * *}$ & $-0.109^{* * *}$ & $0.223^{* * *}$ & $-0.330^{* * *}$ & 4097 & 488 & $162.9^{* * *}$ & $31.7^{* * *}$ \\
\hline Electronic Equipment & WiP & $86.2 \%$ & $3.91 \%$ & $0.086^{* * *}$ & $-0.050 * * *$ & $0.098^{* * *}$ & $0.018^{* * *}$ & $0.831^{* * *}$ & $-0.116 * * *$ & $0.165^{* * *}$ & $-0.302^{* * *}$ & 4088 & 490 & $124.8^{* * *}$ & $34.2 * * *$ \\
\hline Electronic Equipment & FG & $98.0 \%$ & $4.51 \%$ & $0.067 * * *$ & $-0.016^{*}$ & $0.097^{* * *}$ & $0.034^{* * *}$ & 0.408 & $-0.101 * * *$ & $0.147^{* * *}$ & $-0.251 * * *$ & 4048 & 481 & $58.8^{* * *}$ & $10.6^{* * *}$ \\
\hline Machinery & $\mathrm{RM}$ & $91.3 \%$ & $2.81 \%$ & $0.049 * * *$ & $-0.022 * * *$ & $0.078^{* * *}$ & $0.025^{* * *}$ & $0.766^{* *}$ & $-0.068 * * *$ & $0.128^{* * *}$ & $-0.286 * * *$ & 2935 & 300 & $159.7^{* * *}$ & $17.7^{* * *}$ \\
\hline Machinery & WiP & $97.9 \%$ & $4.01 \%$ & $0.062 * * *$ & $-0.016 * * *$ & $0.081 * * *$ & $0.024^{* * *}$ & $1.436 * * *$ & $-0.078 * * *$ & $0.128^{* * *}$ & $-0.304^{* * *}$ & 2911 & 300 & $81.5^{* * *}$ & $10.9 * * *$ \\
\hline Machinery & FG & $96.0 \%$ & $3.71 \%$ & $0.058^{* * *}$ & $-0.017 * * *$ & $0.075^{* * *}$ & $0.016 * * *$ & 0.326 & $-0.074 * * *$ & 0.003 & $-0.256 * * *$ & 2895 & 297 & $101.3^{* * *}$ & $28 * * *$ \\
\hline Pharmaceutical Products & RM & linear & $7.63 \%$ & $0.096 * * *$ & -0.029 & $0.054^{* * *}$ & $0.076^{* * *}$ & $6.219 * * *$ & $-0.083 * * *$ & $0.725^{* * *}$ & $-0.422^{* * *}$ & 1495 & 200 & $49 * * *$ & $14.8^{* * *}$ \\
\hline Pharmaceutical Products & WiP & linear & $5.69 \%$ & $0.069 * * *$ & 0.002 & $0.055^{* * *}$ & $0.068^{* * *}$ & $6.285^{* * *}$ & $-0.103 * * *$ & $0.678^{* * *}$ & $-0.373 * * *$ & 1479 & 195 & $32.3^{* * *}$ & $5.2^{* * *}$ \\
\hline Pharmaceutical Products & FG & $90.2 \%$ & $4.95 \%$ & $0.095 * * *$ & $-0.047 *$ & $0.053^{* * *}$ & $0.090^{* * *}$ & $4.551 * * *$ & $-0.090 * * *$ & $0.464 * * *$ & $-0.349 * * *$ & 1509 & 205 & $19.2^{* * *}$ & $3.9^{* *}$ \\
\hline Medical Equipment & RM & $92.5 \%$ & $4.07 \%$ & $0.073^{* * *}$ & $-0.030 * *$ & $0.069 * * *$ & $0.045^{* * *}$ & $2.180^{* *}$ & $-0.076 * *$ & $0.231^{* * *}$ & $-0.238^{* * *}$ & 1784 & 240 & $39.9^{* * *}$ & $5 * * *$ \\
\hline Medical Equipment & WiP & linear & $5.29 \%$ & $0.070^{* * *}$ & -0.032 & $0.064^{* * *}$ & $0.046^{* * *}$ & $2.992^{* * *}$ & $-0.115 * * *$ & $0.172^{* *}$ & $-0.217^{* * *}$ & 1768 & 239 & $22.9^{* * *}$ & $6.6^{* * *}$ \\
\hline Medical Equipment & FG & linear & $7.55 \%$ & $0.097^{* * *}$ & -0.005 & $0.046^{* * *}$ & $0.050 * * *$ & $2.287^{* *}$ & $-0.094 * * *$ & $0.152^{*}$ & $-0.242 * * *$ & 1766 & 237 & $37.6^{* * *}$ & $7.8^{* * *}$ \\
\hline Computers & $\mathrm{RM}$ & $85.4 \%$ & $3.78 \%$ & $0.081^{* * *}$ & $-0.063 * * *$ & $0.123^{* * *}$ & $0.038^{* * *}$ & $1.938^{* *}$ & $-0.061^{* *}$ & 0.077 & $-0.366^{* * *}$ & 1954 & 274 & $23.6^{* * *}$ & $11.8^{* * *}$ \\
\hline Computers & WiP & $90.5 \%$ & $6.28 \%$ & $0.114^{* * *}$ & $-0.046 * *$ & $0.121^{* * *}$ & $0.027^{* * *}$ & $1.701^{*}$ & $-0.089 * * *$ & 0.136 & $-0.344 * * *$ & 1928 & 269 & $46.9 * * *$ & $17.3^{* * *}$ \\
\hline Computers & FG & $85.5 \%$ & $2.44 \%$ & $0.055^{* * *}$ & $-0.031 *$ & $0.115^{* * *}$ & $0.033^{* * *}$ & -0.049 & $-0.088 * * *$ & 0.086 & $-0.287 * * *$ & 1931 & 270 & $17.7^{* * *}$ & $3.2^{* *}$ \\
\hline Construction Materials & $\mathrm{RM}$ & $78.9 \%$ & $0.94 \%$ & $0.027^{* * *}$ & $-0.020^{* * *}$ & $0.068^{* * *}$ & 0 & $1.325^{* * *}$ & $-0.063 * * *$ & $0.257^{* * *}$ & $-0.213^{* * *}$ & 1726 & 181 & $132.1 * * *$ & $14.6^{* * *}$ \\
\hline Construction Materials & WiP & linear & $2.10 \%$ & $0.023 * * *$ & -0.002 & $0.066^{* * *}$ & 0.007 & $1.043^{* * *}$ & $-0.051 * * *$ & $0.272^{* * *}$ & $-0.230 * * *$ & 1715 & 179 & $63.8^{* * *}$ & $3.7^{* *}$ \\
\hline Construction Materials & FG & $74.9 \%$ & $0.16 \%$ & $0.014^{* *}$ & $-0.020^{* * *}$ & $0.065^{* * *}$ & 0.004 & $0.911^{* *}$ & $-0.047 * * *$ & $0.278^{* * *}$ & $-0.216 * * *$ & 1709 & 177 & $48.9^{* * *}$ & $4.1^{* *}$ \\
\hline Measuring and Control Equipment & $\mathrm{RM}$ & $97.9 \%$ & $4.14 \%$ & $0.066 * * *$ & $-0.018 * *$ & $0.091^{* * *}$ & $0.035^{* * *}$ & $1.382 *$ & $-0.055^{* * *}$ & 0.119 & $-0.241 * * *$ & 1796 & 191 & $57^{* * *}$ & $12.6 * * *$ \\
\hline Measuring and Control Equipment & WiP & $88.4 \%$ & $2.95 \%$ & $0.061 * * *$ & $-0.029 * *$ & $0.096 * * *$ & $0.040^{* * *}$ & 1.088 & $-0.057 * * *$ & 0.113 & $-0.243 * * *$ & 1788 & 189 & $42.6^{* * *}$ & $9.2^{* * *}$ \\
\hline Measuring and Control Equipment & FG & $77.0 \%$ & $1.19 \%$ & $0.052^{* * *}$ & $-0.049 * * *$ & $0.080^{* * *}$ & $0.024^{* * *}$ & $2.091^{* * *}$ & $-0.045^{* *}$ & $0.171^{*}$ & $-0.301^{* * *}$ & 1759 & 189 & $17.5^{* * *}$ & $11.3^{* * *}$ \\
\hline Automobiles and Trucks & $\mathrm{RM}$ & $95.7 \%$ & $1.95 \%$ & $0.033^{* * *}$ & $-0.012 * *$ & $0.030^{* * *}$ & $0.014 * * *$ & $1.627^{* * *}$ & $-0.031 * * *$ & $0.261^{* * *}$ & $-0.297 * * *$ & 1590 & 176 & $77.2^{* * *}$ & $8.3^{* * *}$ \\
\hline Automobiles and Trucks & WiP & linear & $1.72 \%$ & $0.021^{* * *}$ & 0.002 & $0.031^{* * *}$ & $0.012^{* * *}$ & $1.826^{* * *}$ & $-0.035 * * *$ & $0.217^{* * *}$ & $-0.276 * * *$ & 1579 & 175 & $101.5^{* * *}$ & $4 * *$ \\
\hline Automobiles and Trucks & FG & linear & $3.08 \%$ & $0.036^{* * *}$ & -0.003 & $0.027^{* * *}$ & $0.012^{* * *}$ & $1.384^{* * *}$ & $-0.037 * * *$ & $0.170^{* * *}$ & $-0.220 * * *$ & 1582 & 177 & $38.2^{* * *}$ & $11.2^{* * *}$ \\
\hline Consumer Goods & $\mathrm{RM}$ & $92.3 \%$ & $2.11 \%$ & $0.040 * * *$ & $-0.019 * * *$ & $0.052^{* * *}$ & $0.007^{*}$ & $0.598 * *$ & $-0.044 * * *$ & $0.257^{* * *}$ & $-0.219 * * *$ & 1379 & 153 & $82.5^{* * *}$ & $7.9 * * *$ \\
\hline Consumer Goods & WiP & linear & $1.88 \%$ & $0.022^{* * *}$ & -0.01 & $0.053^{* * *}$ & $0.008^{* *}$ & $0.588^{*}$ & $-0.047 * * *$ & $0.246^{* * *}$ & $-0.194 * * *$ & 1369 & 150 & $27.8^{* * *}$ & $7.1 * * *$ \\
\hline Consumer Goods & FG & $92.3 \%$ & $3.11 \%$ & $0.053^{* * *}$ & $-0.018^{* * *}$ & $0.059 * * *$ & $0.013^{* * *}$ & 0.197 & $-0.039 * * *$ & $0.198^{* * *}$ & $-0.176 * * *$ & 1378 & 153 & $92.1^{* * *}$ & $16.6^{* * *}$ \\
\hline Chemicals & $\mathrm{RM}$ & linear & N/A & 0.002 & -0.003 & $0.025^{* * *}$ & $0.011 * * *$ & -0.066 & $-0.041 * * *$ & $0.176^{* * *}$ & -0.101 & 942 & 107 & $38.7^{* * *}$ & $2.8^{*}$ \\
\hline Chemicals & WiP & linear & $2.02 \%$ & $0.024^{* * *}$ & 0.001 & $0.028^{* * *}$ & 0.007 & -0.69 & $-0.053^{* * *}$ & 0.096 & -0.066 & 931 & 102 & $24.5^{* * *}$ & 1.8 \\
\hline Chemicals & FG & linear & $4.66 \%$ & $0.060 * * *$ & -0.011 & $0.030 * * *$ & 0.002 & 0.919 & $-0.059 * * *$ & $0.134^{* *}$ & $-0.201 * *$ & 940 & 105 & $26 * * *$ & $13.6 * * *$ \\
\hline Food Products & $\mathrm{RM}$ & linear & N/A & 0.007 & $-0.012 *$ & 0.003 & $0.018^{* * *}$ & -0.152 & $-0.028^{*}$ & -0.024 & $-0.152^{* * *}$ & 560 & 68 & $13.4^{* * *}$ & 0.8 \\
\hline Food Products & WiP & linear & N/A & 0.008 & -0.004 & 0.005 & $0.013^{* *}$ & $-0.575^{* *}$ & $-0.024^{*}$ & -0.013 & $-0.142^{* * *}$ & 554 & 67 & $38.3^{* * *}$ & 2 \\
\hline Food Products & FG & linear & N/A & -0.016 & $0.019 * *$ & 0.01 & $0.014^{* *}$ & 0.02 & $-0.030 * *$ & -0.008 & $-0.121 * * *$ & 554 & 68 & $32.8^{* * *}$ & 0.9 \\
\hline Steel Works Etc. & $\mathrm{RM}$ & linear & $3.98 \%$ & $0.050^{* * *}$ & -0.011 & $0.043^{* * *}$ & $0.021 * * *$ & $2.747^{* * *}$ & $-0.037 * * *$ & $0.118^{* *}$ & $-0.606 * * *$ & 1190 & 133 & $22.9^{* * *}$ & 2.1 \\
\hline Steel Works Etc. & WiP & $83.1 \%$ & $1.66 \%$ & $0.042^{* * *}$ & $-0.030 * * *$ & $0.040 * * *$ & $0.019 * * *$ & $3.256^{* * *}$ & $-0.030 * * *$ & $0.109 * *$ & $-0.596 * * *$ & 1181 & 131 & $20 * * *$ & 1.3 \\
\hline Steel Works Etc. & FG & $98.4 \%$ & $3.92 \%$ & $0.057^{* * *}$ & $-0.013 * *$ & $0.037^{* * *}$ & $0.018^{* * *}$ & $2.670^{* * *}$ & $-0.049 * * *$ & 0.023 & $-0.486 * * *$ & 1186 & 132 & $30 * * *$ & $6 * * *$ \\
\hline
\end{tabular}

* $(p<0.05),{ }^{* *}(p<0.01), * * *(p<0.001)$ $3.92 \%$ $0.057 * * *-0.013 * *$ \begin{tabular}{lll}
$0.018^{* * *}$ & $2.670^{* * *}$ & $-0.049^{* * *}$ \\
\hline
\end{tabular}

Table 8: Regression summary (continued on next page) 


\begin{tabular}{|c|c|c|c|c|c|c|c|c|c|c|c|c|c|c|c|}
\hline Industry & $\begin{array}{l}\text { Inventory } \\
\text { Componen } \\
\text { t }\end{array}$ & $\begin{array}{l}\text { Percentile } \\
\text { before } \\
\text { maximum } \\
\text { point }\end{array}$ & $\begin{array}{l}\text { Change in } \\
\text { ebit/sales by } \\
\text { one s.d. } \\
\text { increase in ELI }\end{array}$ & ELI & $\mathrm{ELI}^{2}$ & Delta_sales & Log_sales & Emp_at & Debt_ratio & CAPX_at & XSGA_at & $\mathrm{N}$ & Firms & $\begin{array}{l}\text { Kleiberge } \\
\text { n-Paap } \\
\text { statistic }\end{array}$ & $\begin{array}{l}\text { Davidson- } \\
\text { MacKinnon } \\
\text { test of } \\
\text { exogeneity }\end{array}$ \\
\hline Business Supplies & RM & linear & $1.75 \%$ & $0.022^{* * *}$ & -0.005 & $0.049 * * *$ & 0.006 & -0.327 & $-0.052^{* * *}$ & 0.076 & $-0.283^{* * *}$ & 887 & 103 & $72.1^{* * *}$ & 0.6 \\
\hline Business Supplies & WiP & linear & $2.76 \%$ & $0.029 * * *$ & 0 & $0.048^{* * *}$ & $0.017^{* * *}$ & -0.573 & $-0.055^{* * *}$ & 0.075 & $-0.282^{* * *}$ & 879 & 103 & $26.6^{* * *}$ & 1.7 \\
\hline Business Supplies & FG & $79.7 \%$ & $0.54 \%$ & $0.023^{* * *}$ & $-0.022^{* * *}$ & $0.048^{* * *}$ & $0.015^{* * *}$ & -0.435 & $-0.056 * * *$ & 0.073 & $-0.244 * * *$ & 878 & 99 & $26.1^{* * *}$ & 2.2 \\
\hline Apparel & $\mathrm{RM}$ & linear & $2.03 \%$ & $0.025^{* * *}$ & -0.005 & $0.069^{* * *}$ & 0 & 0.153 & $-0.070^{* * *}$ & 0.089 & $-0.130 * * *$ & 1247 & 141 & $55.8^{* * *}$ & 1.3 \\
\hline Apparel & WiP & $85.9 \%$ & $1.39 \%$ & $0.027^{* * *}$ & $-0.016 * *$ & $0.073^{* * *}$ & 0.001 & -0.198 & $-0.072 * * *$ & 0.087 & $-0.099 * * *$ & 1240 & 141 & $27.3^{* * *}$ & $3.6^{* *}$ \\
\hline Apparel & FG & $93.3 \%$ & $2.41 \%$ & $0.043^{* * *}$ & $-0.019 *$ & $0.064^{* * *}$ & -0.003 & $-0.348^{*}$ & $-0.052^{* * *}$ & $0.134^{*}$ & $-0.138^{* * *}$ & 1248 & 143 & $14.6^{* * *}$ & 0.4 \\
\hline Electrical Equipment & $\mathrm{RM}$ & linear & $4.69 \%$ & $0.058^{* * *}$ & 0.001 & $0.057^{* * *}$ & -0.003 & -0.2 & $-0.106 * * *$ & 0.046 & $-0.345^{* * *}$ & 853 & 80 & $33^{* * *}$ & $28.2^{* * *}$ \\
\hline Electrical Equipment & WiP & $74.5 \%$ & $0.13 \%$ & $0.029 * * *$ & $-0.029 * *$ & $0.060^{* * *}$ & -0.004 & -0.459 & $-0.120 * * *$ & 0.073 & $-0.318^{* * *}$ & 853 & 78 & $16.1^{* * *}$ & $7.5^{* * *}$ \\
\hline Electrical Equipment & FG & linear & $2.33 \%$ & $0.026^{* * *}$ & 0.002 & $0.061^{* * *}$ & -0.006 & -0.582 & $-0.100 * * *$ & 0.095 & $-0.265^{* * *}$ & 850 & 78 & $43.6^{* * *}$ & 0.1 \\
\hline Rubber and Plastic Products & $\mathrm{RM}$ & linear & $1.58 \%$ & $0.019 * * *$ & 0.002 & $0.033^{* * *}$ & -0.001 & $0.913 *$ & $-0.082 * * *$ & 0.016 & $-0.318^{* * *}$ & 784 & 94 & $19.5^{* * *}$ & $2.4^{*}$ \\
\hline Rubber and Plastic Products & WiP & linear & $1.09 \%$ & $0.012^{* *}$ & 0.004 & $0.032^{* * *}$ & -0.007 & 0.628 & $-0.071 * * *$ & -0.003 & $-0.295^{* * *}$ & 778 & 94 & $14.7^{* * *}$ & $2.3^{*}$ \\
\hline Rubber and Plastic Products & FG & linear & N/A & 0 & 0 & $0.033^{* * *}$ & -0.004 & $0.777^{*}$ & $-0.076 * * *$ & 0.025 & $-0.299 * * *$ & 783 & 94 & $34.8^{* * *}$ & $2.3^{*}$ \\
\hline Recreational Products & RM & linear & $8.73 \%$ & $0.101^{* * *}$ & 0.014 & $0.085^{* * *}$ & $0.058^{* * *}$ & -0.611 & $-0.116 * * *$ & 0.185 & $-0.453^{* * *}$ & 548 & 65 & $14.9^{* * *}$ & $7.1^{* * *}$ \\
\hline Recreational Products & WiP & linear & $3.12 \%$ & $0.035^{*}$ & 0 & $0.076^{* * *}$ & $0.049^{* * *}$ & $-2.096 * * *$ & $-0.116 * * *$ & 0.079 & $-0.316^{* * *}$ & 544 & 65 & $13.6^{* * *}$ & 0.1 \\
\hline Recreational Products & FG & linear & $8.64 \%$ & $0.117^{* * *}$ & 0.024 & $0.058^{* *}$ & 0.014 & -0.986 & $-0.125 * * *$ & -0.01 & $-0.289 * * *$ & 551 & 67 & $4.2^{* *}$ & $8.1^{* * *}$ \\
\hline Textiles & RM & linear & $3.68 \%$ & $0.046^{* * *}$ & -0.002 & $0.047^{* * *}$ & $0.016^{* * *}$ & -0.04 & $-0.064 * * *$ & $0.113^{* *}$ & $-0.152^{* * *}$ & 754 & 95 & $33.3^{* * *}$ & $5.6^{* * *}$ \\
\hline Textiles & WiP & $93.8 \%$ & $1.66 \%$ & $0.027^{* * *}$ & $-0.010^{* *}$ & $0.043^{* * *}$ & 0.008 & -0.041 & $-0.076 * * *$ & $0.152^{* * *}$ & $-0.107 * *$ & 755 & 98 & $37.9^{* * *}$ & $2.6^{*}$ \\
\hline Textiles & FG & linear & $2.99 \%$ & $0.036^{* * *}$ & -0.002 & $0.039^{* * *}$ & 0.007 & -0.174 & $-0.082^{* * *}$ & $0.132^{* * *}$ & -0.069 & 762 & 100 & $21.5^{* * *}$ & 1.1 \\
\hline Fabricated Products & RM & linear & $1.90 \%$ & $0.023^{* * *}$ & 0.005 & $0.033^{* *}$ & 0.012 & 0.422 & $-0.074 * * *$ & $0.211^{* *}$ & $-0.279 * * *$ & 303 & 35 & $10.6^{* * *}$ & $6.3^{* * *}$ \\
\hline Fabricated Products & WiP & linear & $2.08 \%$ & $0.024^{*}$ & -0.028 & $0.026^{* *}$ & $-0.022^{*}$ & -0.329 & $-0.070 * *$ & 0.153 & $-0.359 * * *$ & 304 & 35 & $6.5^{* *}$ & $4.5^{* *}$ \\
\hline Fabricated Products & FG & linear & N/A & 0.009 & 0.01 & 0.012 & $-0.013 * *$ & -0.177 & $-0.058 * * *$ & 0.149 & $-0.227 * * *$ & 299 & 33 & $18^{* * *}$ & 0.6 \\
\hline
\end{tabular}

${ }^{*}(\mathrm{p}<0.05),{ }^{* *}(\mathrm{p}<0.01),{ }^{* * *}(\mathrm{p}<0.001)$

Average percentage point change in Ebit/Sales by one standard deviation increase in ELI from the mean

Table 8: Regression summary (continuation) 